\title{
DESIGN AND BUILD ANDALIMAN GERANIOL PARFUME MACHINE (ZANTHOXYLUM ACANTHOPODIUM)
}

\author{
Elysabeth Luisa Pakpahan*1), Fenny Cloudya Damanik ${ }^{2)}$, Zulfran Silaban $^{3)}$, \\ Edward Relius Laoli ${ }^{4)}$, Rita Juliani ${ }^{5)}$ \\ ${ }^{1,2,5)}$ Department of Physics, Medan State University \\ ${ }^{4)}$ Department of Chemistry, Medan State University \\ ${ }^{3)}$ Department of Mechanical Engineering, Medan State University \\ Email: pakpahanelysabeth@gmail.com \\ damanik.fenny@gmail.com \\ zulfransilaban225@gmail.com \\ edwardrelius@gmail.com \\ julianiunimed@gmail.com
}

\begin{abstract}
Andaliman has the Latin name Zanthoxylum acanthopodium and is a family of Rutaceae. Andaliman is a native spice from North Sumatra called the golden spicy from North Sumatra. Andaliman farmers in Parsoburan Village, Toba Samosir said that one of the problems in andaliman production is the number of Andaliman fruits that are still not effective, even most of the Andaliman fruit becomes rotten. The design of Andaliman perfume machine has been carried out which aims to increase the usefulness of Andaliman through the manufacture of andaliman perfume as well as to increase the economic value of Andaliman. The method used is by designing a perfume machine and making an official perfume machine, testing the machine and using a perfume machine. Making perfume machines and testing perfume machines was carried out at the UNIMED Mechanical Engineering Workshop and the implementation of machine use activities was carried out in Parsoburan, Toba Samosir Regency. The results obtained from the andaliman smoothing machine were processed as $2 \mathrm{~kg}$ of perfume in a single smoothing process, for the heating stage mixed with $300 \mathrm{~mL}$ ethanol and the results of the perfume $\pm 20 \mathrm{~mL}$ which will be mixed with alcohol according to the strong aroma made.
\end{abstract}

Keywords: Andaliman, Andaliman Perfume, Perfume Machine

\section{RANCANG BANGUN MESIN PARFUM GERANIOL ANDALIMAN (ZANTHOXYLUM ACANTHOPODIUM)}

\author{
Elysabeth Luisa Pakpahan ${ }^{* 1)}$, Fenny Cloudya Damanik ${ }^{2)}$, Zulfran Silaban ${ }^{3)}$, \\ Edward Relius Laoli ${ }^{4)}$, Rita Juliani ${ }^{5}$ ) \\ ${ }^{1,2,5)}$ Jurusan Fisika, Universitas Negeri Medan \\ 4) Jurusan Kimia, Universitas Negeri Medan \\ ${ }^{3)}$ Jurusan Teknik Mesin, Universitas Negeri Medan
}

\begin{abstract}
Abstrak
Andaliman memiliki nama latin Zanthoxylum acanthopodium dan merupakan famili Rutaceae. Andaliman merupakan rempah asli dari Sumatera Utara yang disebut sebagai the golden spicy from North Sumatera. Petani Andaliman di Desa Parsoburan, Toba Samosir mengatakan bahwa salah satu permasalahan dalam produksi andaliman adalah banyaknya buah andaliman yang masih belum berdaya guna dengan baik, bahkan

${ }^{*}$ Komunikasi Penulis
\end{abstract}


sebagian besar buah andaliman menjadi busuk. Telah dilakukan rancang bangun mesin parfum andaliman yang bertujuan untuk meningkatkan keberdaya gunaan andaliman melalui pembuatan parfum andaliman sekaligus untuk meningkatkan nilai ekonomis dari andaliman. Metode yang digunakan dengan cara mendesain mesin parfum dan membuat mesin parfum andaliman, uji coba mesin serta penggunaan mesin parfum. Pembuatan mesin parfum dan uji coba mesin parfum dilakukan di Workshop Teknik Mesin UNIMED dan pelaksanaan kegiatan penggunaan mesin dilaksanakan di Parsoburan, Kabupaten Toba Samosir. Hasil yang diperoleh produksi dari mesin penghalus andaliman yang diolah sebagai parfume sebanyak $2 \mathrm{~kg}$ dalam sekali proses penghalusan, untuk tahap pemanasan dicampur dengan $300 \mathrm{~mL}$ etanol dan hasil parfum yang $\pm 20 \mathrm{~mL}$ yang akan di campur dengan alkohol sesuai dengan kuat aroma yang dibuat.

Kata Kunci: Andaliman, Parfum Andaliman, Mesin.

\section{Pendahuluan}

Andaliman (Zanthoxylum Acanthopodium) merupakan salah satu tumbuhan yang dijadikan bumbu masakan khas daerah Sumatera Utara yang disebut sebagai the golden spicy from North Sumatera. Andaliman dimanfaatkan sebagai rempah pada masakan adat Batak. Masakan yang menggunakan andaliman umumnya lebih tahan lama (Wongso, 2012).

Hasil penelitian Parhusip (2006) menunjukkan bahwa rendemen ekstrak bubuk buah andaliman mengandung minyak atsiri 8.01\%. Penelitian Yasni (2001) menunjukkan bahwa terdapat 11 komponen aktif minyak atsiri andaliman dengan 5 komponen utama, yaitu apinen, limonene, geraniol, citronellol dan geranil asetat. Komponen minyak atsiri tersebut dapat menghambat pertumbuhan patogen (E. coli, Pseudomonas, B.cereus, dan S.aureus) dan kapang (Fusarium sp, Penicillium sp dan Aspergillus flavus).

Hasil wawancara TIM PKM-T dengan petani andaliman di Desa Parsoburan, Toba Samosir mengatakan bahwa salah satu permasalahan dalam produksi andaliman adalah banyaknya buah andaliman yang masih belum berdaya guna dengan baik, bahkan sebagian besar buah andaliman menjadi busuk. Mitra kerja mengatakan bahwa sebagian buah andaliman telah diolah dalam bentuk bubuk dan sambal namun penghasilan mitra tidak meningkat dan masih banyak andaliman yang belum diefektifkan hasilnya.

Solusi tepat guna yang ditawarkan tim PKM-T untuk mengatasi masalah mitra adalah membuat rancangan atau varian lain dari pengelolaan andaliman yaitu parfum. Andaliman mengandung minyak atsiri yang biasanya digunakan untuk membuat parfum.
Pembuat andaliman sebagai parfum menggunakan beberapa langkah salah satunya adalah mengekstrak andaliman. Proses pengekstrakan andaliman dihaluskan dan diendapkan serta dicampur dengan alkohol. Mengubah andaliman menjadi parfum menggunakan teknologi berupa mesin parfum. Andaliman dijadikan minyak atsiri sebagai parfum diharapkan mampu meningkatkan keberdayagunaan andaliman. Proses dijadikannya andaliman menjadi minyak atsiri adalah dengan proses distilasi atau penyulingan yaitu proses pemisahan dua cairan atau lebih dengan berdasrkan perbedaan tekanan uap masing-masing zat (Guenther, 1987 dalam Nugraheni et al., 2016).

\section{Bahan dan Metode}

Kegiatan yang dilakukan dimulai dengan mendesain dan membuat mesin parfum serta eksperimen atau uji coba alat. pada bulan April 2019 sampai Juni 2019. Pembuatan mesin dan uji coba mesin parfum dilakukan di Workshop Teknik Mesin UNIMED dan pendampingan lapangan dilaksanakan di Parsoburan, Kabupaten Toba Samosir.

Alat dan bahan yang digunakan dalam proses pembuatan mesin parfum dan parfum andaliman tertera pada Tabel 1 dan Tabel 2.

Tabel 1. Alat pembuatan mesin parfum

\begin{tabular}{cll}
\hline No. & \multicolumn{1}{c}{ Nama Alat } & Keterangan \\
\hline 1 & $\begin{array}{l}\text { Besi Plat 1,2 mm } 54 \times 63 \\
\mathrm{~cm}\end{array}$ & $1 \mathrm{pcs}$ \\
2 & Kabel & 3 meter \\
3 & $1 \mathrm{cok}$ & $1 \mathrm{pcs}$ \\
4 & Saklar 15 Amper & $1 \mathrm{pcs}$ \\
5 & Dinamo 1Hp & $1 \mathrm{pcs}$ \\
& & Bersambung... \\
\hline
\end{tabular}




\begin{tabular}{cll}
\hline.. Sambungan & \\
6 & Gilingan FFC & $1 \mathrm{pcs}$ \\
7 & Tali kupas & $1 \mathrm{pcs}$ \\
8 & Polly & $1 \mathrm{pcs}$ \\
9 & Besi Siku & 1 bungkus \\
10 & Baut Siku & 2 kotak \\
11 & Kompor & $1 \mathrm{pcs}$ \\
12 & Pipa $3 / 4 \times 0,75 \mathrm{~mm}$ & $1 \mathrm{pcs}$ \\
13 & $2 \times 0,75 \mathrm{~mm}$ & $1 \mathrm{pcs}$ \\
14 & Aluminium foil & $1 \mathrm{pcs}$ \\
15 & Panci stainless & $2 \mathrm{pcs}$ \\
16 & Claim universal grifin & $3 \mathrm{pcs}$ \\
17 & Boshead & $3 \mathrm{pcs}$ \\
18 & Gunting & $1 \mathrm{pcs}$ \\
19 & Boiling duran & $1 \mathrm{Liter}$ \\
20 & Sumbat silicon $41 \times 40 \times 40$ & $1 \mathrm{pcs}$ \\
21 & Kertas pasir & $1 \mathrm{pcs}$ \\
22 & Cat semprot & $3 \mathrm{pcs}$ \\
23 & Dempul & $1 \mathrm{~kg}$ \\
24 & Selang & $1,5 \mathrm{~m}$ \\
25 & Klem selang & $2 \mathrm{pcs}$ \\
\hline
\end{tabular}

Tabel 2. Bahan pembuatan parfum

\begin{tabular}{|cl}
\hline No. & \multicolumn{1}{c}{ Nama Bahan } \\
\hline 1 & Andaliman \\
2 & Etanol $96 \%$ \\
3 & Etanol Absolute \\
4 & P6 \\
\hline
\end{tabular}

Tahap desain mesin, hal-hal yang dilakukan adalah sebagai berikut:

a) Langkah pertama yang diambil adalah menggambar dengan gambar teknik modifikasi mesin parfum andaliman. Perancangan digunakan perangkat lunak SolidWork.

b) Menghitung kebutuhan bahan yang diperlukan untuk membuat mesin parfum.

c) Merancang mekanisme pembuatan parfum.

d) Melakukan perakitan mesin parfum Bahagian ini tahapan pembuatan mesin parfum geraniol Andaliman.

\section{Hasil dan Pembahasan}

A. Desain mesin parfum andaliman

Rancangan desain mesin dilakukan dengan menggunakan software solidwork. dengan dimensi T.133,4 x P.530 x L.750 cm. Desain mesin andaliman dengan tampak depan, samping dan atas terlihat pada Gambar 1,2 , dan 3 .

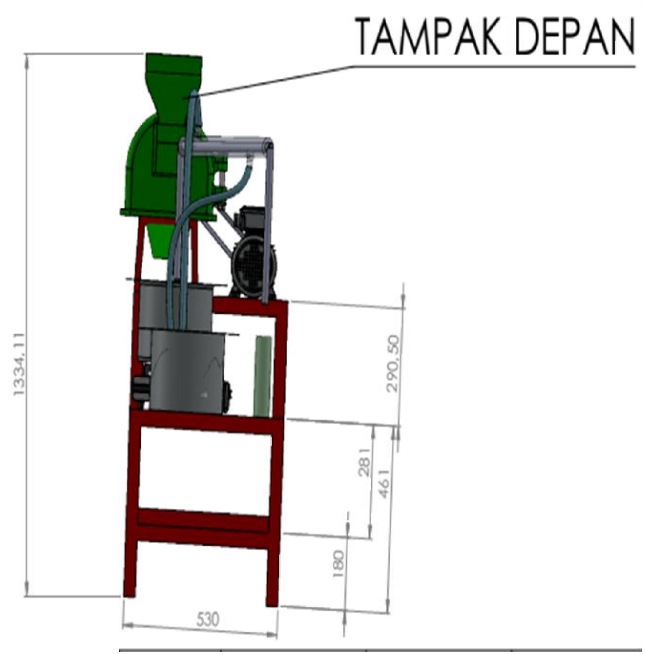

Gambar 1. Bagian mesin parfum andaliman tampak depan.

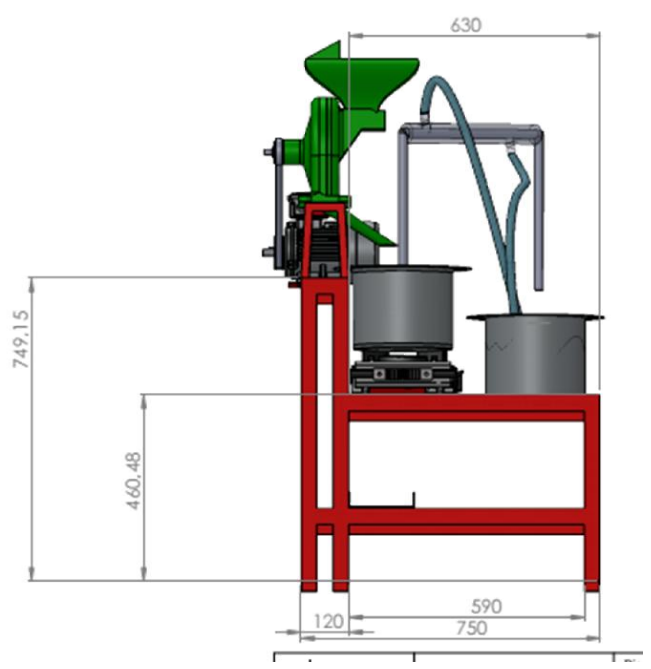

Gambar 2. Rancangan mesin parfum andaliman dengan tampak samping.

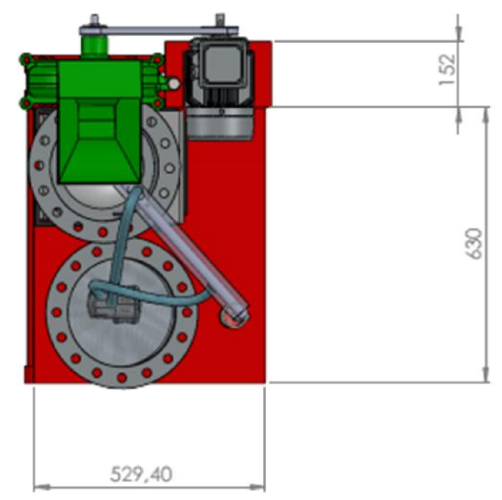

Gambar 3. Rancangan mesin parfum andaliman dengan tampak atas. 
Secara keseluruhan bagian mesin diperlihatkan pada Gambar 4

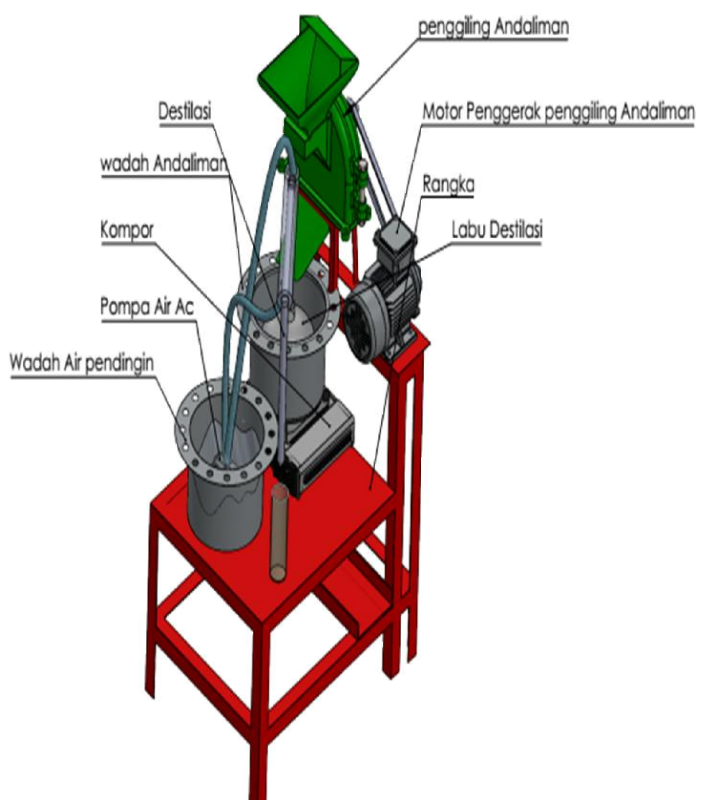

Gambar 4. Bagian mesin parfum andaliman.

Gambar 4 memperlihatkan secara keseluruhan bagian mesin parfum andaliman yang terdiri dari motor listrik, mesin pencacah andaliman, kompor gas dan tabung destilasi dan tabung gas.

Motor listrik yang merupakan penggerak berfungsi mengubah energi listrik menjadi energi mekanis. Motor listrik dikategorikan menjadi berbagai jenis berdasarkan konstruksi dan mekanisme operasi (Syavira dkk, 2018). Motor listrik yang digunakan daya pemakaian listrik $0.75 \mathrm{~kW}$ dengan daya 1 HP dan voltase 220 Volt dengan 4.75 A. Daya motor mempengaruhi kecepatan putar mesin penggiling atau mencacah andaliman dengan $2800 \mathrm{r} / \mathrm{min}$.

Sistem destilasi dilengkapi kompor gas dan pendingin yang digunakan untuk menghasilkan parfum. Rangka merupakan tempat dudukan dari sistem mesin andaliman dan labu destilasi tempat percampuran andaliman dengan etanol untuk selanjutnya dilakukan proses pemanasan untuk mendidihkan capuran etanol dan bubuk andaliman dan kemudian dialirkan ke pendinginan untuk mendapatkan ekstrak parfume andaliman.

\section{B. Pembuatan mesin Parfume Andaliman}

Pembuatan mesin di mulai dari penyediaan alat dan bahan, pembuatan rangka dari besi siku sesuai ukuran sebagai kerangka dudukan, pembuatan bak pencacah, pengelasan mesin pencacah dan motor, pemsanagan system destilasi dan hasil berupa mesin parfume andaliman (Gambar 5).

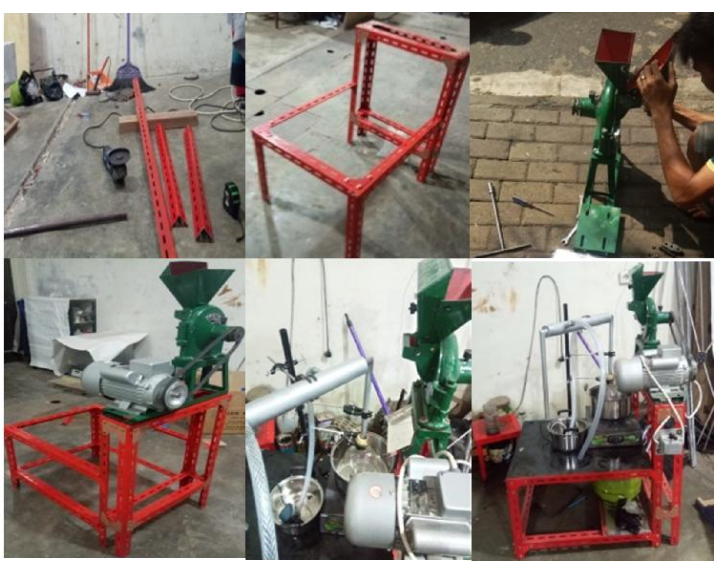

Gambar 5. Proses pembuatan mesin andaliman.

Gambar 5. Memperlihatkan rangka tempat dudukan mesin terbuat dari besi siku lubang dengan tebal $1 \mathrm{~mm}$. Bak pencacah andaliman di rakit dengan motor penggerak serta pemasangan sistem destilasi. Keseluruhan rancang bangun mesin parfume andaliman diperlihatkan pada Gambar 6.

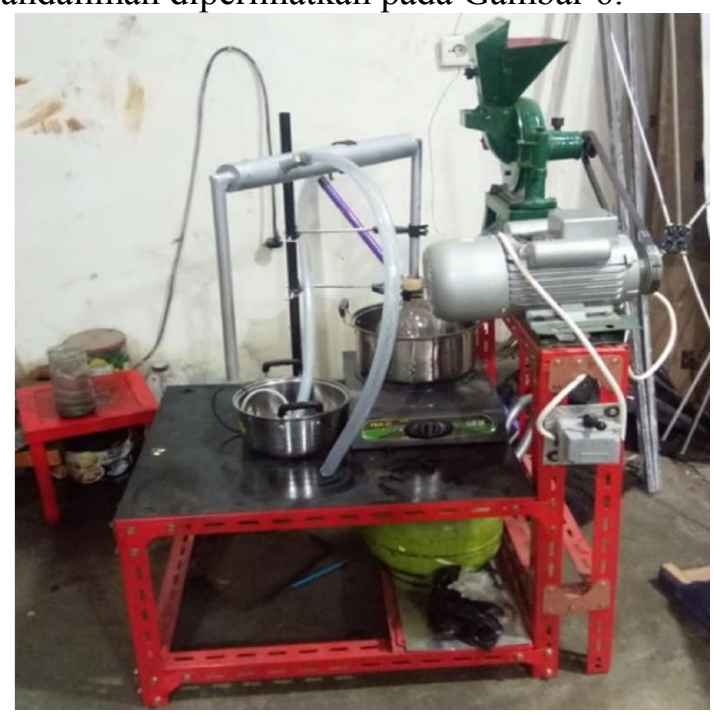

Gambar 6. Mesin parfum andaliman. 


\section{Kerja Mesin Parfum Andaliman}

Mesin parfum andaliman bekerja dengan tujuan melakukan penggilingan andaliman menjadi bubuk dan membuat parfum andaliman dengan aroma andaliman yang khas. Langkah-langkah penggunaan mesin parfum andaliman adalah sebagai berikut.

1. Penggilingan andaliman

Tahapan dalam penggilingan andaliman, yaitu: keringkan andaliman selama tiga hari dalam suhu kamar, lalu masukkan hasil pengeringan andaliman kedalam mesin penggiling. Kapasitas mesin penggiling dalam sekali penggilingan adalah 2 kilogram. Mesin penggiling memiliki rated input voltage $220 \mathrm{~V} / 50 \mathrm{~Hz}$ dengan $1480 \mathrm{rpm}$.

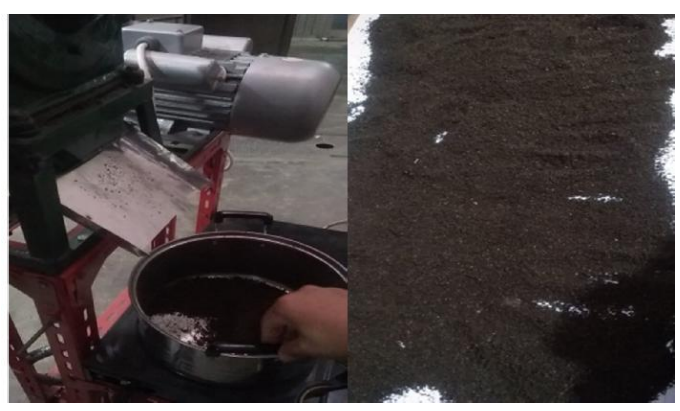

Gambar 7. Penggilingan andaliman.

\section{Destilasi Uap}

Destilasi uap dilaksanakan setelah andaliman sudah menjadi bubuk, kemudian dilakukan maserasi. Tahap maserasi dilakukan dengan mencapurkan bubuk andaliman dengan etanol $96 \%$ pada perbandingan $1: 2$ dan di diamkan selama kurang lebih 3 hari. Hasil maserasi dimasukkan kedalam labu destilasi uap lalu ditutup rapat, nyalakan api sampai suhu air mencapai $78^{\circ} \mathrm{C}$ (Fibriari dkk, 2012). Tunggu selama kurang lebih 2-3 jam. Hasil minyak atsiri yang diperoleh dari $300 \mathrm{~mL}$ campuran andaliman dan etanol diperoleh ekstrak sebanyak $20 \mathrm{ml}$. Ekstrak yang dihasilkan merupakan minyak atsiri kemudian dicampur dengan pelarut yaitu etanol absolute. Dalam tahapan destilasi uap terjadi kondensasi. Kondensasi atau pengembunan adalah perubahan wujud benda ke wujud yang lebih padat, seperti gas (atau uap) menjadi cairan. Kondensasi terjadi ketika uap didinginkan menjadi cairan, tetapi dapat juga terjadi bila sebuah uap dikompresi (yaitu, tekanan ditingkatkan) menjadi cairan, atau mengalami kombinasi dari pendinginan dan kompresi. Cairan yang telah terkondensasi dari uap disebut kondensat. Sebuah alat yang digunakan untuk mengkondensasi uap menjadi cairan disebut kondenser. Kondenser umumnya adalah sebuah pendingin atau penukar panas yang digunakan untuk berbagai tujuan, memiliki rancangan yang bervariasi, dan banyak ukurannya dari yang dapat digenggam sampai yang sangat besar.


Gambar 8. Proses destilasi dan parfum andaliman.

\section{Kesimpulan dan Saran}

Berdasarkan pembahasan yang telah diuraikan, dapat disimpuklan yaitu:

1. Pendesainan dan pembuatan mesin parfum andaliman dengan menggunakan motor listrik sebagai penggerak mesin pencacah dapat mempercepat peghalusan andliman.

2. Sistem destilasi yang di rancang memudahkan proses evaporasi sehingga dapat dilakukan di luar laboratorium.

3. Parfum andaliman yang di hasilkan dari rancangan mesin parfume sangat membantu dalam pengolahan andaliman menjadi parfum yang andaliman.

Rekomendasi selanjutnya diharapkan:

1. Bak penampungan hasil destilasi digunakan wadah kecil yang ditutup dengan stereform dan aluminium koil untuk mengurang proses penguapan minyak atsiri yang di produksi. 
2. Pemberian campuran alkohhol pada ekstrak andaliman di gunakan untuk tingkat kelembutan aroma andaliman.

\section{Ucapan Terima Kasih}

TIM PKM-T mengucapkan terimakasih kepada RISTEKDIKTI yang mendanai kegiatan PKM-T 2019, Bapak Rektor Universitas Negeri Medan dan jajarannya, dosen Pendamping, mitra di Desa Parsoburan, Toba Samosir, teman-teman seperjuangan Fakultas Teknik Universitas Negeri Medan yang telah bekerja sama dengan TIM di dalam rancang bangun mesin parfume andaliman.

\section{Daftar Pustaka}

Fibriari Ira, Gunawa, \& Hastuti Rum, 2012. Pengkayaan Alkohol Ciu Berkonnang dengan Metode Destilasi Adsofptif Menggunakan Zeolit Alam dan Silika Gel. Jurnal Kimia Sains dan Aplikasi 15 (3) 2012. Hal 79-83.

Nugraheni Krisnawati Setyaningrum Nugraheni, Khasanah Lia Umi, Utami Rohula, Ananditho Baskara Katri, 2016. Pengaruh Perlakuan Pendahuluan dan Variasi Metode Destilasi terhadap
Karakteristik Minyak Atsiri Daun Kayu Manis (C. Burmanii). Jurnal Teknologi Hasil Pertanian, Vol. IX, No. 2, Agustus 2016. Hal. 51-64

Parhusip, A.J.N. 2006. Kajian mekanisme antibakteri ekstrak andaliman (Zanthoxylum acanthopodium DC) terhadap Bakteri Pathogen Pangan. [Disertasi]. Sekolah Pascasarjana Institut Pertanian Bogor. Bogor.

Syavira Riri, Nasution Tiaminah, Nabila Raisa, \& Juliani Rita. 2018. Design And Build Salak (Salacca Sumatrana) Embalming Machine With Conveyor. Jurnal Geliga Sains 6 (1), Hal 60-64.

Yasni, S., 2001. Aktivitas Antimikroba minyak atsiri buah andaliman (Zanthoxylum acanthopodium DC.) dan antarasa (Litsea Cubeba) terhadap Bakteri dan Kapang serta Profil Deskriptif Komponen Aktif Penyusunnya. Di dalam Nuraida L., Dewanti-Hariyadi R., editor. Pangan tradisional basis bagi industri pangan fungsional dan suplemen. Pusat Kajian Makanan Tradisional Institut. Pertanian Bogor. Bogor. Hal 130-138.

Wongso, 2012. Buah Andaliman Khas SumateraUtara. http://www.b isnisukm. com. [Diakses 30 Oktober 2018]. 